Третьякова Т. М., Наиіональний університет

«Одеська юридична академія»

https://orcid.org/0000-0003-2552-5850

Станішевська В. І., Уманський державний педагогічний університет ім. Павла Тичини

https://orcid.org/0000-0003-3324-8988

\title{
ПСИХОЛОГІЧНІ МАРКЕРИ ОСОБИСТОСТІ, ЩО ПЕРЕЖИВАЄ ВНУТРІШНЬООСОБИСТІСНИЙ КОНФЛІКТ
}

У статті обгрунтовуються психологічні маркери особистості, яка переживає внутрішньоособистісний конфлікт. Для послідовного вивчення внутрішньоособистісних конфліктів виявлено характерні для них ознаки у когнітивній, емоційній та поведінковій сферах.

Ключові слова: внутрішньоособистісний конфлікт; особистість; когнітивна сфера; емоиійна сфера; поведінкова сфера.

Постановка проблеми. Зіткнення між різними властивостями i відношеннями, устремліннями й тенденціями у внутрішньому світі людини спричиняють виникнення у неї різноманітних поведінкових реакцій. Ці реакції можуть мати як позитивну, так i негативну спрямованість. Це обумовлено тим, що внутрішньоособистісні конфлікти, як невід'ємний компонент соціального буття особистості можуть виконувати дві функції: позитивну (конструктивну) i негативну (деструктивну). В останньому випадку особистість не усвідомлює власні недоліки, або ж усвідомивши, не здатна їх усунути, вона віддаляється від реальних проблем життя, перебуває у болісному i невирішеному конфлікті із собою. Для неї події реального життя стають зовнішніми, оскільки вона зосереджується на внутрішніх подіях i не бачить шляхів подолання особистісної проблеми. Отже, існує необхідність у виявленні тих психологічних маркерів, які свідчили б про переживання особистістю внутрішньоособистісного конфлікту та його конструктивну чи деструктивну спрямованість.

Аналіз останніх досліджень i публікацій. Аналіз науково-психологічної літератури свідчить про те, що конфлікти як соціально-психологічну досліджувало багато проблему, українських, радянських і зарубіжних науковців, зокрема
В. С. Василюк,
I. В. Ващенко,

Є. А. Донченко,

О. С. Калмикова,

А. Р. Лурія,

Г. М. Дубчак,

Ю. О. Олександровський,

О. М. Леонтьєв, В. М. Радчук, М. В. Савчин, В. В. Столін, С. А. Чистяков, В. Франкл, Е. Фромм та ін. $\mathrm{У}$ них розкрито теоретичні та практичні аспекти проявів конфліктів у різних сферах діяльності особистості та умови їхнього вирішення. Ці дослідження дозволили значно розширити сучасні уявлення про деякі аспекти вивчення внутрішньоособистісних конфліктів та особливостей їхнього прояву. Разом із тим вони не дозволяють вирішити існуючі проблеми щодо інтерпретації сутності цього явища. Одним із шляхів, який дозволяє тією чи іншою мірою подолати ці труднощі, є застосування не окремих, часткових методик, а системного аналізу.

Мета статті - обгрунтувати психологічні маркери особистості, яка перебуває у стані внутрішньоособистісного конфлікта.

Методи дослідження - аналіз, узагальнення, порівняння, систематизація наукових джерел із проблеми дослідження.

Виклад основного матеріалу. Як зазначас С.А. Чистяков, якщо обставини иття потребують від особистості таких дій та умов, які перебувають на межі іï адаптивних можливостей чи навіть перевершують наявні у неї резерви, виникає стан внутрішньоособистісного конфлікту [1].

Існує діалектичний зв'язок між ситуацією й особливостями особистості при виникненні внутрішньоособистісного конфлікту, який можна виразити у такий спосіб: чим гостріше і несподіваніше діють негативні чинники середовища, тим меншу роль відіграють особистісні якості, i навпаки, при зменшенні масивності i гостроти впливу цих чинників індивідуальний склад особистості набуває більшого значення. Тут можна говорити про певний психологічний простір адаптаційних можливостей особистості.

У конкретної людини можливість 


\section{Питання психології}

прояву внутрішньоособистісного конфлікту визначається складною взаємодією негативних чинників середовища та іiі індивідуально-психологічних особливостей, за якої саме ці чинники знаходять найбільш слабке місце в особистості для опору. Спонувальною силою внутрішньоособистісного конфлікту $\epsilon$ суперечності між різними мотивами, цілями, цінностями приблизно однієї сили, але протилежно спрямовані. Важливою умовою виникнення конфлікту є рівень значущості, уявлення особистості про внутрішньоособистісну суперечність. Основними відмінностями внутрішньоособистісного конфлікту від внутрішньоособистісної суперечності є те, що при конфлікті протилежно спрямовані тенденції суб'єктивно переживаються особистістю як абсолютно несумісні, і те, що при цьому стані в особистості відбувається порушення рівня організації власної поведінки та діяльності, що у свою чергу повинно відображатися в іï когнітивній, емоційній i поведінковій сферах. Особливе місце у цьому процесі посідає таке явище, як тривога. Емоція типу «тривоги», виконуючи сигнальну та оцінюючу функції за несприятливих для особистості ситуацій, сприяе розвитку психологічного захисту особистості, що стимулює iї пошуки у вирішенні наявних суперечностей і тому відіграє важливу роль у динаміці перебігу конфлікту.

Високий рівень тривожності особистості як стану під час внутрішньоособистісного конфлікту зумовлений декількома причинами: зовнішньою ситуацією, у якій вона перебуває, і яку вона оцінює як несприятливу та таку, що несе загрозу особистісно значущим основам майбутньої діяльності; наявністю труднощів у реалізації важливих для неї цілей; негативним, суб'єктивним сприйняттям вжитих особистістю заходів для зміни існуючої ситуації, що призводить до сприйняття ситуації як ще більш загрозливої, що як результат провокує більш високий рівень тривожності.

Значній частині людей, які перебувають у стані конфлікту, притаманна особистісна тривожність як властивість особистості, що впливає на підвищення інтенсивності тривожності як психічного стану. Тому на початковій стадії внутрішньоособистісного конфлікту, який особистістю сприймається як важка, загрозлива ситуація, для неї буде характерним більш високий рівень тривожності. Крім сигнальної функції, тривога виконує також функцію оцінки конфліктної ситуації. Оцінка загрозливої ситуації приводить до запуску пристосувальних дій, захисних механізмів та інших форм адаптаційної активності, що має на меті усунення джерела потенційної небезпеки.

При несприятливих ситуаціях особистість використовуе весь комплекс захисних психологічних заходів для зміни цієї ситуації у потрібному для себе напрямку. Найбільш часто серед захисних механізмів використовуються: витіснення, проекція, заперечення (відмова), раціоналізація, сублімація, ізоляція і регресія, а часом i гіперкомпенсаційні психологічні механізми. Відзначимо, що загрозлива (конфліктна) ситуація, якщо вона оцінюється суб'єктом як суб'єктивно значуща, вимагає розгортання певних контрзаходів, адаптивних реакцій, які б дозволили знизити тривожний стан. Характеризуючи внутрішньоособистісного конфлікту, необхідно зазначити, що цей стан виникає тоді, коли вжиті особистістю контрзаходи (адаптивні реакціï) не принесли на певний момент бажаного результату. Тому суб'єктивно внугрішньоособистісний конфлікт сприймається нею як свого роду «тимчасова психологічна безпорадність» [2]. Таким чином, на початкових етапах конфлікту, у ситуації, що загрожує тим чи іншим особистісно значущим диспозиціям особистості, підвищується рівень тривоги. Тривога має сигнальну й оцінюючу функції. Як результат дії тривоги особистість розгортає адаптивні реакції щодо вирішення певної ситуації. Якщо ж вжиті заходи не принесли їй бажаного результату, то виникає стан внутрішньоособистісного конфлікту, що суб̆'єктивно сприймається як стан психологічної безпорадності, зупинки, коли потрібна зміна або дій, або якихось внутрішніх диспозицій щодо вирішення сформованої конфліктної ситуації. Можна припустити, що під час внутрішньоособистісного конфлікту буде відбуватися порушення оптимальної регуляції поведінки та діяльності особистості. У свою чергу, ці порушення повинні відображатись в тих чи інших змінах когнітивних, емоційних, поведінкових сферах особистості, а також зміні раніше існуючої системи відношень між ними.

Поведінкова, когнітивна, емоційна сфери особистості пов'язані із таким компонентом внутрішнього світу як емоційне протистояння особистості, що, на 


\section{Питання психології}

думку О. С. Калмикової, «...розрізняється за рівнем організації - від ситуативних настроїв, конкретних реакцій до узагальнених світоглядних почуттів» [3, c. 34]. Однак емоційні стани будь-якого рівня складності $\epsilon$ відображенням реально існуючих об'єктивних зв'язків між мотивами і ціннісними орієнтаціями особистості та іiі конкретної діяльності. Висунуте положення про прояви конфлікту у різних сферах особистості підводить до питання виокремлення у них основних психологічних маркерів цього стану.

Розглядаючи когнітивну сферу i, насамперед, розуміючи іï як сферу свідомості особистості, найбільш важливими психологічними маркерами будуть особливості образу «Я» особистості та iï самооцінки. К. Роджерс вважає, що ступінь задоволеності людини у житті у першу чергу залежить від того, якою мірою іiї досвід, іiі «Я актуальне» і «Я ідеальне» погоджуються між собою. Тому під час виникнення конфлікту в особистості з'являється виражена суперечність між цими сторонами «образу Я», що і можна вважати одним із психологічних маркерів прояву цього стану. Висунуте ним положення про суперечності між «Я актуальним» i «Я - ідеальним» як прояв конфлікту відображає важливий аспект когнітивної сфери особистості, яка переживає цей стан. Через значущість наявних суперечностей особистості, неможливість досягнення нею важливих цілей відбувається зміна внутрішнього образу, оцінки особистістю себе. Ця зміна характеризується, 3 одного боку, більш негативно зумовленою оцінкою наявних в особистості індивідуальнопсихологічних якостей, що стають внутрішньою перешкодою реалізації наявних у неї цілей, а 3 іншого боку - вираженим бажанням мати в ідеалі особистісні риси, які б сприяли самореалізації і подоланню наявних труднощів. Тому при переживанні особистістю внутрішнього конфлікту відображенням у свідомості цих змін буде виражено різницю між образами «Я актуальне» і «Я - ідеальне», а також суперечливість цього образу у цілому $[4$, c. 32].

Під час внутрішньоособистісного конфлікту можна спостерігати також зниження самооцінки особистості. Як основна складова самосвідомості, самооцінка $\epsilon$ важливим регулятором іï поведінки. Від самооцінки залежать взаєморозуміння людини 3 оточуючими, іi критичність, вимогливість до себе, ставлення до невдач. Тим самим самооцінка впливає на ефективність діяльності людини та на подальший розвиток особистості. Самооцінка тісно пов'язана із рівнем домагань людини, тобто ступенем труднощів щодо досягнення цілей, які вона ставить перед собою. Розбіжності між реальними можливостями людини веде до того, що вона починає неправильно себе оцінювати, внаслідок чого іiі поведінка стає неадекватною.

Таким чином, у когнітивній сфері найбільш важливими критеріями внутрішньоособистісного конфлікту особистості є: суперечливість «образу Я», велика неузгодженість між образами «Я актуальне» і «Я - ідеальне», заниження самооцінки, а також усвідомлення свого стану як свого роду «психологічної безпорадності», з якої особистість на той чи інший момент не бачить оптимального виходу.

Внутрішньоособистісний конфлікт відображається в емоційній сфері особистості. Психологічним маркером конфлікту в емоційній сфері особистості, що переживає цей стан, $є$ перевага негативно спрямованих емоцій. Вони у свою чергу $є$ чинником інтеграції цілеспрямованих реакцій організму, процесом, що поєднує і спрямовує можливості особистості пристосовуватись до зовнішнього світу, критерієм корисності чи шкідливості цієї функціональної діяльності. внутрішньоособистісному конфлікті дії особистості не приносять їй бажаного результату, у цьому стані вона не реалізує повною мірою особистісно значущі потреби, цілі, а це, у свою чергу, призводить до погіршення настрою, переважання негативних емоцій.

Своєрідність регулюючої функції емоцій полягає у відображенні ними співвідношення мотивів i конкретних результатів, причому це відображення відбувається у безпосередній формі, як переживання. Емоції регулюють діяльність відповідно до особистісного змісту дій і результатів. Оскільки ситуація внутрішньоособистісного конфлікту для індивіда $є$ значущою, вона викликає певні емоційні переживання, а у зв'язку із тим, що у тій чи інший ситуації особистість не досягає бажаного результату, знак емоційних переживань, як правило, $\epsilon$ негативним. I. С. Кон так характеризував взаємозв'язок між конфліктною ситуацією й емоціями: «...Конфліктна ситуація, яку 


\section{Питання психології}

індивід не може вирішити, викликає у нього негативні емоції величезної сили, що загрожують його психіці i самому існуванню» [5, с. 265].

Наявність зниженого настрою, переваги негативних емоцій внутрішньоособистісному конфлікті можна характеризувати i через таке поняття, як депресія, що має більш широке значення. Патологічна депресія є одним 3 основних психіатричних синдромів. Проте депресія може виникнути й у психічно здорових людей як результат переживання значущих для них несприятливих подій, невдач $\mathrm{y}$ реалізації особистісно значущих цілей. Депресія у психічно здорових людей одержала назву «функціональний стан депресії» чи у інших джерелах як «невротична депресія». Сутність невротичної депресії полягає у тому, що людина усвідомлює несприятливий психологічний вплив, у неї погіршується настрій, вона відчуває почуття власної неповноцінності, принижує, сварить себе, шукає у собі різні недоліки. Усе це супроводжується порушеннями сну, апетиту та ін. Але у будь-якому випадку на перший план виходить стійке зниження настрою, що залежить від ситуації.

Депресивні реакції виникають тоді, коли звичні форми адаптивних реакцій чи захисних механізмів не спрацьовують. Основні ознаки депресивної особистості виявляються в іiі крихкості, уразливості «Я», у результаті чого єдиним надійним способом захисту від життєвих стресів, втрат i розчарувань виявляється, на думку Є. Т. Соколової, «депресивна в'язниця». Виникнення депресії $€$ сигналом, що сформований стиль емоційного реагування, який містить витіснення, проекцію, формування реакції, виявився неефективним [6, с. 155]. Крім того, для індивідів, що перебувають у стані внутрішньоособистісного конфлікту, характерною $є$ так звана «когнітивна тріада депресії», яка охоплює негативні почуття, які стосуються оцінки «Я». Цю тріаду складають: по-перше, низька самооцінка, почугтя меншовартості у тих чи інших сферах психологічного функціонування; по-друге, компонент атрибутивного каузального стилю, що $\epsilon$ підсумком у самозвинуваченні та самокритиці; по-третє, втрата віри у себе, очікування негативного [6]. Усі ці ознаки тією чи іншою мірою $є$ характерними для тих, хто перебуває у стані внутрішньоособистісного конфлікту, хоча виразність і глибина функціонального депресивного стану (невротичної депресії) у них індивідуально є різними.

Інтенсивність i можливість появи депресивного стану у людини залежить від двох основних чинників: по-перше, від виду конфлікту, а по-друге, від індивідуальних особливостей особистості, що переживає конфлікт. Таким чином, для особистості, що перебуває у стані внутрішньоособистісного конфлікту, в емоційній сфері характерною $є$ переважання зниженого настрою, негативних емоцій. Крім того, індивід може відчувати в певному стані той чи інший ступінь депресії.

Слід зазначити, що стан внутрішньоособистісного конфлікту відображається й у поведінковій сфері особистості. Найбілыш характерними психологічними маркерами внутрішньоособистісного конфлікту у поведінковій сфері $\epsilon$ насамперед зниження якості та інтенсивності спілкування, зниження об'єктивних показників навчальної та професійної діяльності і суб'єктивного задоволення від контактів з людьми. Для тих, хто перебуває у стані внугрішньоособистісного конфлікту, характерним є порушення потреби (мотиву) аффіліації. Дослідники потребу (мотив) аффіліації характеризують як: прагнення заводити дружбу i мати прихильність; радіти іншим людям і жити разом із ними; співпрацювати і спілкуватися із ними; любити; приєднуватися до груп. Метою мотиву аффіліації $\epsilon$ взаємний $i$ довірчий зв'язок, де кожен з індивідів приймає партнера, по-товариськи підтримує і симпатизує йому. Аналізуючи дієвий аспект поведінки особистості, що перебуває у стані внутрішньоособистісного конфлікту, можна припустити, що для неї буде характерним зниження об'єктивних показників навчальної чи професійної діяльності. До об'єктивних показників можна віднести, насамперед, успішність в оволодінні знаннями, поточну успішність, результати праці і т.п. Як правило, у стані внугрішньоособистісного конфлікту можна спостерігати зниження мотивації до навчальної чи професійної діяльності, ці люди більш орієнтовані на власні внутрішні проблеми, i тому, як правило, виявляють менше ініціативи, у них знижується поточна успішність, погіршується ставлення до виконання професійних обов'язків. Однак суб'єктивне ставлення цих людей до зниження показників діяльності, в залежності від виду конфлікту й особливостей особистості, $€$ різним. Для одних це стає додатковим джерелом негативних емоцій, переживань, 


\section{Питання психології}

інші ж ставляться індиферентно, зосереджуючись лише на власних внугрішніх проблемах.

Крім зазначених психологічних маркерів доцільно виокремлювати ще й інтегральний маркер конфлікту, що виражається у порушенні нормального механізму адаптації особистості. М. Сельє під адаптацією розуміє «систему дій, спрямованих на досягнення рівноваги із середовищем» [7, с. 54]. Тому система психологічної адаптації людини перебуває у постійній готовності до виконання властивих ій функцій. Під час внутрішньоособистісного конфлікту особистість відчуває труднощі щодо досягнення своїх цілей, створення оптимального психологічного захисту від впливу несприятливих чинників середовища, щодо досягнення внутрішньої узгодженості. Отже, в умовах конфлікту відбувається тимчасове порушення нормального функціонування системи психологічної адаптації. Ці порушення під час внутрішньоособистісного конфлікту будуть виявлятися як на різних рівнях системи адаптації, так і у системі у цілому.

Особливості, що розвивалися, впливали на життя особистості і проявлялися в особливостях характеру, емоційно-вольових якостях, мотиваційно-цінносних орієнтаціях особистості, у їі досвіді - усе це створює той чи інший ступінь здатності людини реагувати на можливі труднощі, утворює основу адаптації до несприятливих психологічних чинників, дозволяє активно i цілеспрямовано ї змінювати. У внутрішньоособистісному конфлікті відбувається нищення процесу вибору оптимального шляху подолання чи виходу зі складного становища, можливості адекватної і цілеспрямованої зміни несприятливих чинників, що впливають на особистість. Це зумовлено тим, що під час внутрішньоособистісного конфлікту суперечності охоплюють основні особистісно важливі, змістовно утворюючі аспекти індивіда, які відіграють особливу роль у виробленні оптимальної програми досягнення важливих для особистості цілей. Таким чином, психологічним маркером внутрішньоособистісного конфлікту можна вважати порушення системи нормальної адаптаційної взаємодії особистості із середовищем, які можна розглядати і як тимчасову дезадаптацію особистості.

Висновки та перспективи подальших досліджень. Для послідовного вивчення внутрішньоособистісних конфліктів виявлено характерні для них психологічні маркери: у когнітивній сфері - пізнавальні процеси: неуважність; зниження самооцінки; внутрішня розбіжність між образами, «Я - ідеальне» і «Я -актуальне», «хочу» і «можу», «потрібно» і «можу»; в емоційній сфері - перевага негативних психічних станів: астенічний настрій; тривожність; напруга; апатія; агресія; у поведінковій сфері - прояви поведінкових реакцій: зниження інтенсивності й ефективності комунікативних зв'язків; зниження результативності службової діяльності; зниження успішності навчальної діяльності; намагання усамітнитися (уникнення міжособистісних контактів).

Незважаючи на актуальність цієї проблеми для суспільства загалом, вона залишається ще недостатньо теоретично та експериментально розробленою. Підтвердженням цієї думки $є$ те, що на сьогоднішній день у психології відсутні експериментальні дослідження внутрішньоособистісних конфліктів та їхній вплив на результати навчальної та професійної діяльності. Не вивчено психологічні чинники, які детермінують їхнє виникнення і прояви під час організації навчально-виховного процесу, а також не визначено особливості психологічної роботи щодо їхнього попередження та вирішення.

\section{Список використаних джерел}

1. Чистяков С.А. Внутрішньоособистісні конфлікти та особливості їх психопрофілактики і психокорекції у курсантів вищого військового навчального закладу: дис. канд. психол. н. Національна академія Прикордонних військ України ім. Богдана Хмельницького. Хмельницький, 2003. 162 с.

2. Астапов В.М. Функциональный подход к изучению тривоги. Психологический журнал. 1992. T.13. №5. C. 111-120.

3. Калмыкова Е.С. Исследования психотерапии за рубежом: некоторые методологические проблемы. Психологический журнал. 1992. Т.13. №6. С. 54-64.

4. Роджерс К. Взгляд на психотерапию, становление человека. М.: Изд-во гр. «Прогресс». 1994. С. 196-202.

5. Кон И.С. В поисках себя: Личность и её самосознание. М.: Политиздат, 1984. 335 с.

6. Соколова Е.Т. Особенности самооценки при невротическом развитии личности. Дис... канд. психол. наук. М.: МГУ, 1991. С. 65-81.

7. Селье Г. Стресс без дистресса. М.: Прогресс, 1982. 123 с. 


\section{Питання психології}

\section{References}

1. Chystjakov S.A. (2003) Vnutrishn'oosobystisni konflikty ta osoblyvosti i'h psyhoprofilaktyky i psyhokorekcii' u kursantiv vyshhogo vijs'kovogo navchal'nogo zakladu [Intrapersonal conflicts and features of their psychoprophylaxis and psychocorrection in cadets of higher military school]: dys. kand. psyhol. n. Nacional'na akademija Prykordonnyh vijs'k Ukrai'ny im. Bogdana Hmel'nyc'kogo. Hmel'nyc'kyj. 162 s. (in Ukranian)

2. Astapov V.M. (1992) Funkcional'nyj podhod k izucheniju trevogi [Functional approach to the study of tripods], Psihologicheskij zhurnal. T.13. №5. S. 111-120. (in Russian)

3. Kalmykova E.S. (1992) Issledovanija psihoterapii za rubezhom: nekotorye metodologicheskie problemy [Psychotherapy researches abroad: some methodological problems]. Psihologicheskij zhurnal. T.13. №6. S. 54-64. (in Russian)

4. Rodzhers K. (1994) Vzgljad na psihoterapiju, stanovlenie cheloveka [A look at psychotherapy, the formation of man]. M.: Izd-vo gr. «Progress». S. 196-202. (in Russian)

5. Kon I.S. (1984) V poiskah sebja: Lichnost' i ejo samosoznanie [In search of oneself: Personality and self-awareness]. M.: Politizdat. 335 s. (in Russian)

6. Sokolova E.T. (1991) Osobennosti samoocenki pri nevroticheskom razvitii lichnosti [Features of selfesteem with neurotic personality development]. Dis... kand. psihol. nauk. M.: MGU. S. 65-81. (in Russian)

7. Sel'e G. (1982) Stress bez distressa [Stress without distress]. M.: Progress. 123 s. (in Russian)

\section{Резюме \\ Третьякова Т. М., кандидат политических наук, \\ Национальный университет «Одесская юридическая академия» \\ Станишевская В. И., Уманский государственный педагогический университет им. Павла Тычины \\ ПСИХОЛОГИЧЕСКИЕ МАРКЕРЫ ЛИЧНОСТИ, ПЕРЕЖИВАЮЩЕЙ ВНУТРИЛИЧНОСТНЫЙ КОНФЛИКТ}

В статье обосновываются психологические маркеры личности, переживающей внутриличностный конфликт. Для последовательного изучения внутриличностных конфликтов выявлены характерные для них признаки в когнитивной, эмочиональной и поведенческой сферах.

Ключевые слова: внутриличностный конфликт; личность; когнитивная сфера; эмочиональная сфера; поведенческая сфера.

\section{Summary}

Tretyakova T., associate Professor in polit. sciences, National University «Odessa Law Academy» Stanishevskaya V., Postgraduate Student, Uman Pavlo Tichina State Pedagogical University

\section{PSYCHOLOGICAL MARKERS OF PERSONALITY EXPERIENCING INTERNAL CONFLICT}

In the article the psychological markers of the person who is experiencing an intrapersonal conflict are substantiated. The urgency of the problem of identifying and predicting the nature of the impact of interpersonal conflicts is due to the fact that it needs to be resolved issues not only to find ways to eliminate or prevent crisis forms of conflict experiences, but, above all, to isolate the conditions in which a person can use the positivity of these experiences. For a consistent study of intrapersonal conflicts, characteristic signs in the cognitive, emotional and behavioral spheres have been identified. It is noted that there is a dialectical relationship between the situation and personality traits in the occurrence of intrapersonal conflict, which can be expressed in this way: the more acute and unexpected are negative environmental factors, the less important are the qualities of personality, and vice versa, in reducing the severity of the mass. these factors make the individual's personality composition more important. Here we can talk about a certain "psychological space of adaptive capacity of the individual». Some personal qualities or certain environmental factors narrow this space, reducing the extent to which personal measures are taken to restore the process of human adaptation. In a particular person, the possibility of manifestation of intrapersonal conflict is determined by the complex interaction of negative factors of the environment and individual psychological characteristics, in which these factors find the weakest place in the personality for resistance.

For the serial research of intrapersonal conflict identified characteristic psychological markers: in the cognitive area - cognitive processes: inattention; low self-esteem; internal divergence between the images of "I am perfect» and «I am actual», «want» and «can», «must» and «may»; in the emotional sphere - the advantage of negative mental states: depressive mood; anxiety; tension; apathy; aggression; in the field of behavioral manifestations of behavioral reactions: the reduction in the intensity and effectiveness of communication links; reduced performance; the decline in success of educational activity; the desire to retire (avoidance of interpersonal contact).

Key words: intrapersonal conflict; personality; cognitive sphere; emotional sphere; behavioral sphere. 